\title{
Effective Performance Appraisal Systems in Competitive Schools
}

\author{
Audria Ncube \\ Jameson High School, Mashonganyika Avenue, Corner Warwick Avenue, Kadoma, Zimbabwe
}

\begin{abstract}
Performance appraisal systems need to be effective in improving or sustaining employee performance, otherwise they are a sheer waste of time and money spend on development and implementation. From literature analyses, it became clear that the most significant factor in determining performance appraisal system effectiveness is the acceptance of its users. In a school setting the users are the School Head, Deputy Head, Heads of Departments and all the teachers. In carrying out the study, the researcher took a sample of ten private secondary schools and ten public secondary schools drawn from five of the ten provinces in Zimbabwe. The five provinces are Mashonaland West, Mashonaland East, Mashonaland Central, Harare and Midlands. From each of the five provinces, two private secondary schools and two public secondary schools were chosen. Purposive sampling was used to select information- rich participants for the semi-structured individual interviews. The participants in this case comprised of twenty school heads, twenty heads of departments and twenty senior teachers (ten from public secondary schools and ten from private secondary schools in each category). Stratified, Simple Random and Convenient sampling methods were used for other participants. The Questionnaire Survey was administered to three hundred teachers from private secondary schools and three hundred teachers from public secondary schools. The simple averages, percentages, Chi-Square generated by the use of SPSS 16.0 and Micro Soft Excel were used to analyse the data. Participants have shown their concerns about lack of communication, less emphasis on performance review meetings and uni-source performance evaluation system. However, private secondary schools have implemented new Performance Appraisal system with more emphasis on training. In public secondary schools, teachers are concerned about their training needs and comprehensive performance evaluation. Current research in this paper, has explored number of operational issues regarding ineffective communication between heads and teachers. The study showed that reality was far from the ideal. Heads stressed time pressure. Teachers are less motivated because they are not been encouraged by their heads. Appraisal process is ambiguous because of no clear guidance for conducting it. Teachers and heads use to hesitate performance reviews for avoiding potential conflicts and incompetence of department heads because of no training for this process. The survey and interview findings clearly suggested that there is a need to improve the mechanisms and procedures for the management and implementation of the teacher appraisal process in Zimbabwe by training both the appraisees and appraisers; making the whole process transparent by providing feedback to all stakeholders, especially the appraisees; and reviewing the appraisal system. It is evident that this matter urgently requires major steps being taken. In other words, an effective teacher appraisal system should enable teachers to gain more knowledge and skills so that they may be empowered and thus confident in their service delivery.
\end{abstract}

Keywords: Effective Performance Appraisal, Performance Reviews, Performance Feedback, Performance Rating, Competitive Schools, Result-Based Management

\section{Introduction}

This article draws most of its information from the research the author carried out when he was doing his $\mathrm{PhD}$ thesis titled; "Effectiveness of performance appraisal systems in relation to teacher dedication in public and private secondary schools in Zimbabwe". The research was conducted in five of the ten provinces in Zimbabwe namely, Mashonaland West, Mashonaland East, Mashonaland Central, Midlands and Harare. Part of the information is from the ready literature. The literature provides some possible causes of ineffective performance appraisal systems in schools.

\section{Background to the Study}

The standard of teaching in public secondary schools is characterised by lazy teachers, increasing absenteeism among teachers, general poor quality of tuition and teachers' strikes over salaries and poor working conditions. The Herald (Zimbabwe) paper dated Thursday 5 July 2012 (first page) carries a heading that says "Civil servants give government two week ultimatum". In the story, the Apex Council, which brings together the Public Service
Association, Zimbabwe Teachers Association (ZIMTA), Progressive Teachers Association (PTUZ) and Teachers

Union of Zimbabwe (TUZ) and chaired by Mrs Tendai Chikowore had met the previous day (4 July 2012) with the National Joint Negotiating Council (Government). According to the Apex Council, the government came to the negotiating table "empty handed "The civil servants have given Government a two-week ultimatum to improve their salaries and working conditions or face a nationwide strike. In their demands submitted on the $4^{\text {th }}$ of July 2012, the workers are demanding an all-inclusive salary of US\$564 for the least paid worker and $15 \%$ of the basic salary as rural allowance. The least paid Government worker as of now is getting US\$269 (The Zimbabwean Herald, $5^{\text {th }}$ July 2012). Teachers Union of Zimbabwe President, Mr Lovemore Mufamba, said Government had promised to increase salaries in July, but was now reneging on the agreement. He said, they were invited to the meeting but surprisingly they did not want to talk about welfare issues, but wanted to focus on peripheral issues and non-functional committees, like the resource tracking one which is not a bread and butter issue Progressive Teachers Union of Zimbabwe (PTUZ) Secretary Raymond Majongwe said a political decision was needed to ensure civil servants get an increment. 


\section{International Journal of Science and Research (IJSR) \\ ISSN (Online): 2319-7064}

Index Copernicus Value (2013): 6.14 | Impact Factor (2015): 6.391

The above cases explain lack of motivation on the part of the teachers especially those teaching at public secondary schools. The government does not have enough money to meet the teachers' demands. Despite the dissatisfaction with low salaries that are far below the poverty datum line, teachers get excited when their students perform well in public examinations.

\section{Review of Related Literature}

According to Jacobs et al. (1980), performance appraisal can be described as a systematic attempt to distinguish the more efficient workers from the less efficient workers and to discriminate among strength and weaknesses an individual has across many job elements. In short, performance appraisal is a measurement of how well someone performs job-relevant tasks (Parrill, 1999). These measurements are normally done by the direct supervisor of the ratee and can serve different organisational purposes. Examples are employee selection, disciplinary action, development / feedback, promotion, training / supervision and personnel planning.

Execution of performance appraisal means that underlying assumptions to performance appraisal exist. According to Reinke (2003) one of the most basic assumptions is that employees differ in their contribution to the organisation because of individual performance, and that supervisors are actually able and willing to distinguish between employees. Furthermore, for development purposes one assumes that accurate and timely feedback can change behaviour (Tziner et al., 1992) in a way that the organisation as well as the individual is profiting. According to Tziner and Kopelman (2002), this is fostered through the following mechanisms: raters' identification of employees' strengths and weaknesses, the provision of feedback and the facilitation of communication with supervisors. Another assumed aspect is concerned with the practicality of performance appraisal: Time and costs for development and execution phases of the process do not outperform the organisational win, which is reached by appraising performance (Jacob et al., 1980).

\subsection{Effective Performance appraisal}

According to Chilli (2011), Performance Appraisal is an objective system to judge the ability of an individual employee to perform his tasks. An effective performance appraisal system should focus on the individual and his development, besides helping him to achieve the desired performance. This means that while the results are important, the organization should also examine and prepare its human capital to achieve these results.

A well-conceived Performance Appraisal System should combine approaches to gain the most complete understanding of teaching and that administrators and teachers should work together to create a system that supports teachers as well as evaluate them.

Effective Performance Appraisal System should;

- Be based upon clear standards,

- Encourage professional growth across a teaching career,

- Take account of organizational supports and barriers to effective teaching,
- Empower teachers to examine their work,

- Be based upon multiple sources of evidence.

Performance appraisal, as stated by Gwarada (1997:25) is to evaluate the following of a teacher:

- Lesson presentations (subject content, techniques, subject methodologies and evaluation);

- Managing (leadership skills, inter-personal skills be constituted); - Administrating (record keeping and planning); and

- Organisation of his/her teaching activities.

Effective systems can significantly contribute to the satisfaction and motivation of employees- if they are correctly used. The objectives of the system fall into two categories: evaluative and developmental.

\subsubsection{Evaluative Objective}

The most common decisions based on evaluative objectives concern compensation, which includes merit increases, employee bonuses and other increases in pay. The performance appraisal normally has two-part effect on future pay. In the short run, it may determine merit increases for the following year; in the end, it may determine which employees are promoted into higher paying jobs.

\subsubsection{Development Objectives}

This objective encompasses employee skills and motivation for future performance. Performance feedback is a primary developmental need because all employees want to know how their superior feels about their performance (Grobler et al, 2002:266).

\subsection{Purpose of Performance Evaluation}

The obvious and principal purpose of performance evaluation is to guide an instructor to improve his teaching capability in order to deliver his best. As Seldin (1980) asserts that, as no one is perfect in this world everyone needs to improve at every stage of life. He further emphasized that as students need guidance and advice for their error correction, similarly teachers need more accurate and honest data for their self-improvement in weak areas. Positive improvement in teaching can take place only when they will have large measures of their performance evaluated on kind of facts came out from evaluation results.

Classroom teacher has the responsibility to create an educational program and a classroom environment that is multicultural, gender and ability fair, that is favourable to learning and personal growth and that is based on the commitment that all students can master the basic and essential skills at each grade/form level or course. In addition, the teacher will establish an educational program and environment to foster students' self-esteem, motivation and sense of civic responsibility. Teachers will establish an effective rapport with students and good relationship with parents and other staff members

\subsection{Methods of Performance Evaluation of Teachers}

After determining the evaluation criteria or effective teaching parameters, next question in front of any academic 


\section{International Journal of Science and Research (IJSR) \\ ISSN (Online): 2319-7064}

Index Copernicus Value (2013): 6.14 | Impact Factor (2015): 6.391

institution is how to know whether teaching faculty possesses these qualities? Seldin (1980) emphasized that students, teacher colleagues, administration and teachers themselves take part in this evaluation as "components of the collective judgement of teaching performance". He further explains that students are always able to provide reliable information about teacher performance and his effectiveness regarding teaching. Similarly, peers because they are in same business can give their positive contribution for evaluation process. Teacher self-appraisal, if conducted in accurate and constructive manner not only proves to be an authentic part of whole evaluation information but also an abrupt and effective motivation for performance enhancement.

\subsection{Outcomes of Effective Performance Appraisal}

Common outcomes of an effective performance appraisal process are employees' learning about themselves, employees' knowledge about how they are doing, employees' learning about 'what management values' (Beer, 1981). According to Stephan and Dorfman (1989) outcomes of effective performance appraisal are improvement in the accuracy of employee performance and establishing relationship between performance on tasks and a clear potential for reward. Dobbins, Cardy and Platz- Vieno (1990) pointed out five outcomes, which are, use of evaluations as feedback to improve performance, reduced employee turnover, and increased motivation, existence of feelings of equity among employees, linkage between performance and rewards. Nurse (2005) viewed provision of information for the development of managerial strategies for training and development as an outcome. Teratanavat, Raitano and Kleiner (2006) found outcomes like reduced employee stress, review of overall progress, linkage between current performance and employee's goals, and development of specific action plans for future.

\subsection{Training}

The training in this study is in two ways, the training that is meant to improve the teacher's content knowledge and teaching skills and training on the appraisal system.

\subsubsection{Training to improve the teacher's content knowledge and teaching skills}

According to Andrews (1993: 133-134), training implies the broadening or expanding of a teachers' knowledge or skills so that he will be in a better position to perform his work more effectively. Reitzug (2002:3) contends that training is the traditional and still dominant form of professional development. Training includes direct instruction, skill demonstration and involves workshops and presentations. In addition, training involves instruction by an expert or experienced employee on job processes in an organisation (Grobler et al., 2002:323). Higgs and Higgs (1994:43) capture the essence of training as they state that, "Education and training are about the use that people make of their knowledge and skills, their value to them personally in their living and thinking and they are what the acquisition of knowledge and skills had done to their minds, their attitudes, values, ideas, motives and intentions". According to Cronje et al. (2004:207), training involves providing employees with knowledge, skills, values and attitudes to do a particular job effectively and efficiently.

\subsubsection{Training on the appraisal system}

Nearly all authors agree in the fact that rater must be trained to observe, gather, process, and integrate behaviourrelevant information in order to improve performance appraisal effectiveness. Rudner (1992) for example proposes that training should aim at three goals: First, it should familiarize judges with the measure they will be working with. Second, it must ensure that judges understand the sequence of operations that they must perform. Third, it should explain how the judges should interpret any normative data that they are given.

Because errors are well-ingrained habits, Tziner and Kopelman (2002) state that extensive, training is necessary for avoiding such errors. Therefore, the training should provide trainees with broad opportunities to practice the specified skills, provide trainees with feedback on their practice appraisal performance, and that a comprehensive acquaintance with the appropriate behaviours to be observed. Harris (1988) also points at the necessity of training: Continued training is needed in areas such as goalsetting and monitoring performance on a frequent basis and personal and interactional skills. She proposes that an organisation could provide training as this on a regular basis in such a manner that it becomes an accepted part of the supervisor's position and thus becomes a part of the organisations culture.

In summary, it is a necessary condition that raters are sufficiently trained so that they:

(1) understand the appraisal process; (2) are able to use the appraisal instrument as intended which includes interpreting standards and use of scales; and (3) are able to give effective feedback including goal setting. Acceptance will only be gathered if ratees and raters perceive these conditions to be fulfilled. Furthermore, these skills need to be updated or refreshed on a continuing basis. In addition, ratees should receive a certain form of appraisal training to introduce them to the appraisal system. To attain their acceptance and support of the appraisal system also employees must understand the appraisal system as a whole as well as the behavioural aspects and standards that are used to evaluate their performance

\subsection{Performance feedback}

Giving feedback to the employee generally aims at improving performance effectiveness through stimulating behavioural change. The manner in which employees receive feedback on their job performance is a major factor in determining the success of the performance appraisal system (Harris, 1988). Hearing information about the selfdiscrepant from one's self-image is often difficult and painful. Thus, because feedback may strike at the core of a person's personal belief system it is crucial to set conditions of feedback so that the ratee is able to tolerate, hear, and own discrepant information (Dalton, 1996). Only if conditions facilitate the acceptance of feedback information then the likelihood of change increases. Dalton (1996) further specifies these conditions: The feedback event 


\section{International Journal of Science and Research (IJSR) \\ ISSN (Online): 2319-7064}

Index Copernicus Value (2013): 6.14 | Impact Factor (2015): 6.391

should be a confidential interaction between a qualified and credible feedback giver and ratee to avoid denial, venting of emotions, and behavioural and mental disengagement. In such an atmosphere, discrepancies in evaluations can be discussed and the session can be used as a catalyst to reduce the discrepancies (Jacobs et al., 1980).

Roberts (2003) instead concludes that effective feedback is timely, specific, and behavioural in nature and presented by a credible source. Tziner et al. (1992) were able to prove that when performance feedback is precise and timely it may result in behaviour change, even though job behaviours are generally difficult to modify. Furthermore, performance feedback alone generates improvements to ratees organisational commitment, and particularly to work satisfaction (Tziner and Kopelman, 2002). However, performance feedback combined with goal setting contributes the most strongly to ratees work satisfaction; possibly, since goal setting fosters feelings of participation in work related issues and meaningfulness at work. Tziner and Kopelman (1992) also found that the process of goal setting gives the appraisee a broader picture of the work unit and the Organisations` objectives. Harris (1988) supports the findings about the positive effects of goal setting. She recommends an evaluative interview for providing feedback, which focuses on problem solving, and goal setting and which has high employee involvement. Done this way it is more likely to be satisfying to employees than retrospective, subjective interviews.

\section{Methodology}

In carrying out the study, the researcher took a sample of ten private secondary schools and ten public secondary schools drawn from five of the ten provinces in Zimbabwe. The five provinces are Mashonaland West, Mashonaland East, Mashonaland Central, Harare and Midlands. From each of the five provinces, two private secondary schools and two public secondary schools were chosen. Purposive sampling was used to select information- rich participants for the semi-structured individual interviews. The participants comprised of twenty school heads, twenty heads of departments and twenty senior teachers (ten from public secondary schools and ten from private secondary schools in each category). Stratified, Simple Random and Convenient sampling methods was used for other participants. The Questionnaire Survey was administered to three hundred teachers from private secondary schools and three hundred teachers from public secondary schools. The simple averages, percentages, t-tests, Chi-Square, Multivariate Analysis and ANOVA generated by the use of SPSS 16.0 and Micro Soft Excel were used to analyze the data.

As suggested by Fink (1995), only purposeful statements based upon research objective and hypotheses were included. Some questions were closed to elicit standardized response. Medium of communication was English with focus on use of conventional language. Wording of survey questions/statements was kept simple and unbiased and questions of trivial nature were avoided.

\section{Presentation and discussion of study findings}

The first part of this chapter gives demography of the respondents. The respondents represented by the figures below comprises of the appraisers (school heads and heads of departments (HODs) and appraisees (teachers) from both public and private secondary schools from the five provinces namely Mashonaland West, Mashonaland East, Mashonaland Central, Midlands and Harare. From six hundred and fifty five school heads, heads of departments (HODs) and teachers, three hundred and sixty four (56\%) were males and two hundred and ninety one (44\%) were females. This implies that males are still dominating the teaching profession.

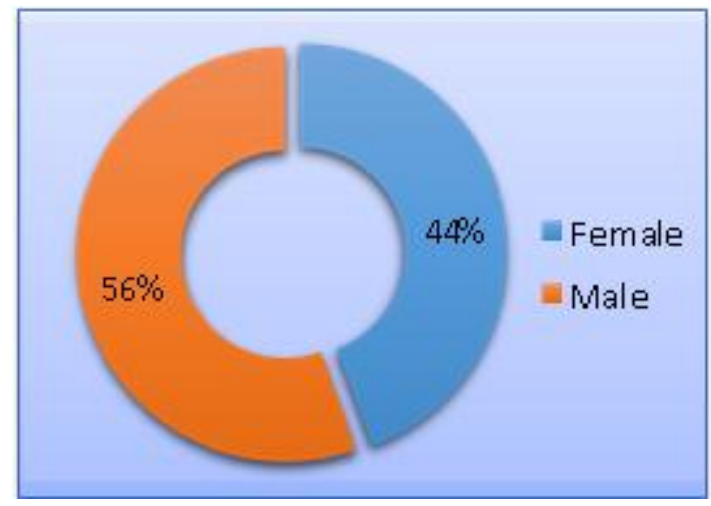

Figure 5.1: Distribution of respondents by gender

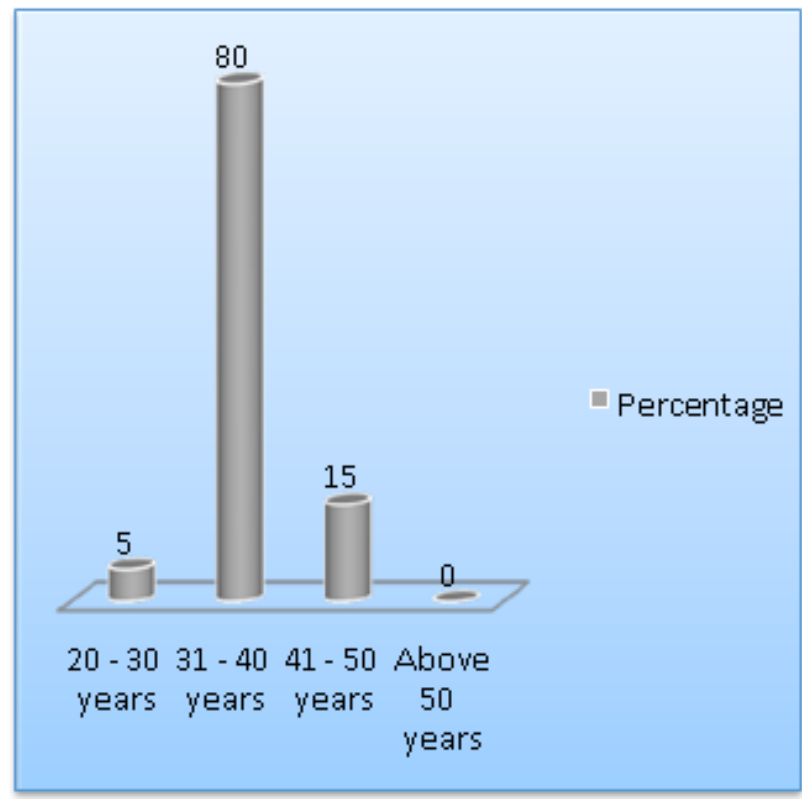

Figure 5.2: Distribution of respondents by age

Figure 5.2 above shows the age distribution of the respondents. Five percent of the appraisers and appraises were in the age group 20-30 years, eighty percent were in the age group 31-40 years, fifteen percent were in the age group 41-50 years and from the sample no respondent was above fifty years. Therefore, the majority of the teachers are the age group 31-40 years. This implies that most of the teachers are mature.

Figure 5.3 below shows the academic qualifications of the respondents. The respondents who had "O" level constituted one percent, respondents who had "A" level added up to 


\section{International Journal of Science and Research (IJSR) \\ ISSN (Online): 2319-7064}

Index Copernicus Value (2013): 6.14 | Impact Factor (2015): 6.391

sixty two percent and respondents who had Bachelor's degree constituted thirty seven percent. This shows that most the teachers are "A" Level Certificate holders. In Africa, Zimbabwe has the highest literacy rate. In fact, it is second to Tunsia.

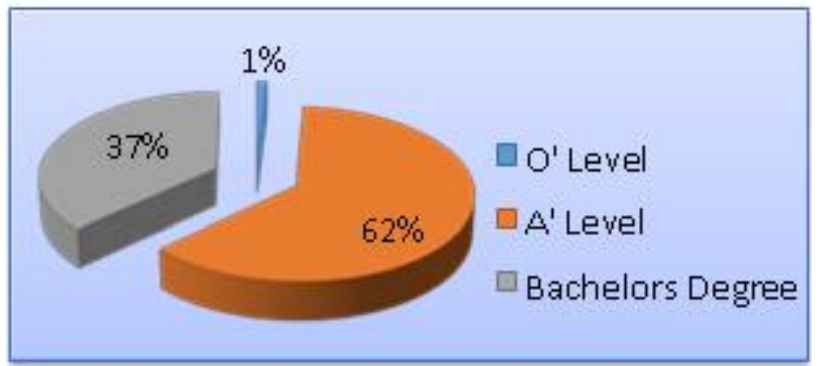

Figure 5.3: Distribution of respondents by academic qualifcations

Figure 4.4 below shows the professional qualification of the respondents. Five percent of the respondents had Certificate in Education, thirty-eight percent had Diploma in Education and fifty-seven percent had Bachelor's degree. This implies that Zimbabwean teaching force comprises of highly educated people.

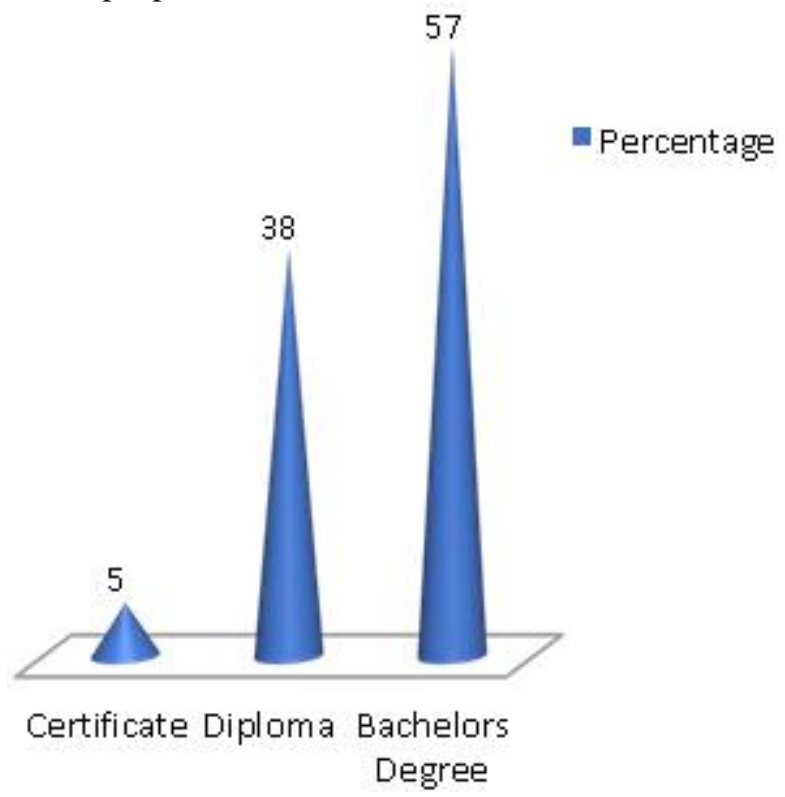

Figure 5.4: Distribution of respondents by professional qualification
Figure 5.5 shows the teaching experience of the respondents. Five percent of the respondents had 3-5 years of teaching experience, forty-eight percent had 6-10 years of teaching experience, thirty two percent had 11-15 years of teaching experience and fifteen percent had 15-20 years of teaching experience. Overall, Zimbabwean-teaching profession still has highly experienced teachers despite losing a number of experienced teachers to neighbouring countries like South Africa and Botswana due to poor working conditions in Zimbabwean Secondary schools especially in public secondary schools

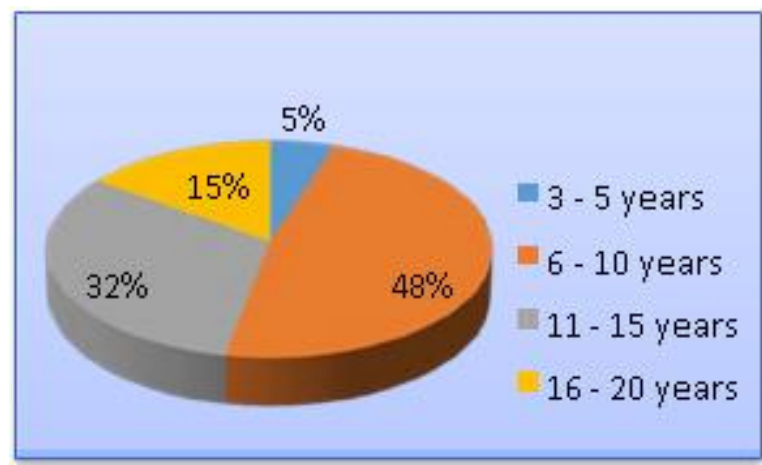

Figure 5.5: Distribution of respondents by teaching experience

Table 5.1 below shows the association between appraisal training and teacher dedication to work. The teachers who received no training on the appraisal system and were classified under the very good category on dedication to work constituted two percent. Those teachers who were trained on the appraisal system and fallen on the very good category on dedication to work constituted twenty-three percent. Therefore, appraisal training increases dedication to work. Teachers need to know the real purpose of the appraisal system, which is mainly to professionally develop the teacher. A teacher who is equipped with the necessary knowledge and teaching skills is bound likely to influence student achievement in a very positive way. Whilst the other purpose of the appraisal system is identifying hardworking teachers and rewarding them by means of promotion or increment of their salaries, the main purpose is to develop the teachers professionally.

Table 5.1: Association between appraisal training and teacher dedication

\begin{tabular}{|c|c|c|c|c|c|c|c|}
\hline \multirow{2}{*}{} & \multirow{2}{*}{} & & \multicolumn{3}{|c|}{ Teacher's dedication to work } & \multirow{2}{*}{ Total } \\
\cline { 4 - 8 } & & & Very poor & Poor & Good & Very Good & 130 \\
\hline \multirow{3}{*}{ Appraisal Training } & \multirow{2}{*}{ No } & Count & 64 & 94 & 9 & 13 & 180 \\
\cline { 3 - 8 } & & $\%$ of Total & $9.8 \%$ & $14.4 \%$ & $1.4 \%$ & $2.0 \%$ & $27.5 \%$ \\
\cline { 3 - 8 } & \multirow{2}{*}{ Yes } & Count & 84 & 136 & 104 & 151 & 475 \\
\cline { 3 - 8 } & & $\%$ of Total & $12.8 \%$ & $20.8 \%$ & $15.9 \%$ & $23.1 \%$ & $72.5 \%$ \\
\hline & & Count & 148 & 230 & 113 & 164 & 655 \\
\cline { 3 - 8 } & & $\%$ of Total & $22.6 \%$ & $35.1 \%$ & $17.3 \%$ & $25.0 \%$ & $100.0 \%$ \\
\hline
\end{tabular}

Table 5.2 below shows the Chi-square test for association between appraisal training and dedication to work. The hypotheses being tested are;

$\mathrm{H} 0$; There is no association between appraisal training and dedication to work.
$\mathrm{H} 1$; There is an association between appraisal training and dedication to work.

The findings are that Chi-square calculated value of 92.201 is greater than the critical value of 7.82 and the p-value of 0.000 is less than 0,05 . Therefore, we reject $\mathrm{H} 0$ at $5 \%$

\section{Volume 5 Issue 6, June 2016} www.ijsr.net 


\section{International Journal of Science and Research (IJSR) \\ ISSN (Online): 2319-7064}

Index Copernicus Value (2013): 6.14 | Impact Factor (2015): 6.391

significance level and conclude that there is an association between appraisal training and dedication to work.

Teachers who receive training on the appraisal system and understand that the appraisal is meant to identify their strengths and weaknesses have positive attitudes towards the system. Their strengths are then enhanced and rewarded and a training programme that seeks to correct the identified weaknesses corrects their weaknesses. When the weaknesses are corrected, the feeling of self-worth can prevail in teachers and this in turn will enhance self-esteem.

Table 5.2: Chi-Square Tests for association between appraisal training and teacher dedication

\begin{tabular}{|c|c|c|c|}
\hline & Value & Df & Asymp. Sig. (2-sided) \\
\hline Pearson Chi-Square & $92.201^{\mathrm{a}}$ & 3 & 0 \\
\hline Likelihood Ratio & 103.008 & 3 & 0 \\
\hline $\begin{array}{c}\text { Linear-by-Linear } \\
\text { Association }\end{array}$ & 76.462 & 1 & 0 \\
\hline N of Valid Cases & 655 & & \\
\hline
\end{tabular}

0 cells $(.0 \%)$ have expected count less than 5 . The minimum expected count is 31.05 .

Table 5.3 shows the rating of the depth of information contained in the feedback. The respondents who rated the depth of information contained in the feedback on the poor category constituted $30.8 \%$, the good category constituted $49 \%$, the very good category constituted $19 / 8 \%$ and the excellent category constituted $0,3 \%$. Some of the respondents who were interviewed on the depth of information contained in the feedback were quick to say that it was poor for there was nothing in the feedback only to here appraisers saying you are doing well. They pointed out that while it is necessary to be praised after doing good work it is also necessary that areas needing improvement be highlighted. However, some of the respondents from private secondary schools interviewed were happy with depth of information contained in the feedback for their strengths, weaknesses were pointed out in friendly manner, and programmes to correct identified weaknesses were suggested by both the appraiser and appraisee.
Table 5.3: Depth of information contained in the feedback

\begin{tabular}{|c|c|c|c|c|}
\hline & Frequency & Percent & Valid Percent & $\begin{array}{c}\text { Cumulative } \\
\text { Percent }\end{array}$ \\
\hline Poor & 202 & 30.8 & 30.8 & 30.8 \\
\hline Good & 321 & 49.0 & 49.0 & 79.8 \\
\hline Very Good & 130 & 19.8 & 19.8 & 99.7 \\
\hline Excellent & 2 & .3 & .3 & 100.0 \\
\hline Total & 655 & 100.0 & 100.0 & \\
\hline
\end{tabular}

Table 5.4 shows the frequency of formal feedback. The respondents placed the frequency of the formal feedback as follows, poor category constituted $50.8 \%$, good category $16.0 \%$, very good category $30.7 \%$ and excellent $2.4 \%$. Most respondents from the public secondary schools interviewed pointed out that the frequency of feedback was poor for they got feedback only twice per year. They expressed dissatisfaction with the frequency of formal feedback adding that it was not helping them improve on their profession for nothing was done after the infrequent feedback. Respondents from private secondary schools expressed satisfaction with the frequency of the formal feedback. They pointed out that immediately after the feedback training programmes were put in place to correct identified weaknesses on the part of the appraisees.

Table 5.4: Frequency of formal feedback

\begin{tabular}{|c|c|c|c|c|}
\hline & Frequency & Percent & Valid Percent & $\begin{array}{c}\text { Cumulative } \\
\text { Percent }\end{array}$ \\
\hline Poor & 333 & 50.8 & 50.8 & 50.8 \\
\hline Good & 105 & 16.0 & 16.0 & 66.9 \\
\hline Very Good & 201 & 30.7 & 30.7 & 97.6 \\
\hline Excellent & 16 & 2.4 & 2.4 & 100.0 \\
\hline Total & 655 & 100.0 & 100.0 & \\
\hline
\end{tabular}

Figure 4.6 shows the quality of ideas presented in the formal feedback. The distribution of the responses were as follows poor category constituted $37 \%$, good category constituted $40 \%$, very good category $22 \%$ and excellent category $1 \%$. Most respondents from the public secondary schools pointed out that no meaningful ideas came out of the feedback. Respondents interviewed from the private secondary schools appreciated the ideas that came from the formal. They pointed out that most of the ideas benefited them.

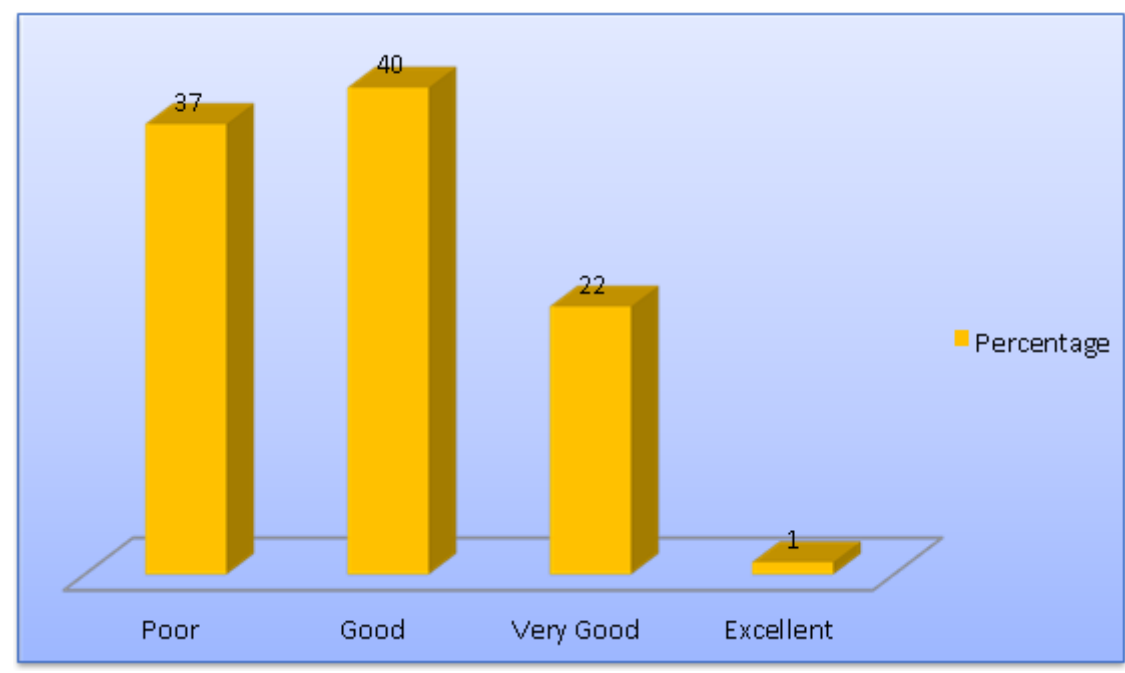

Figure 5.6: Quality of ideas presented in formal feedback

Volume 5 Issue 6, June 2016 www.ijsr.net 


\section{International Journal of Science and Research (IJSR) \\ ISSN (Online): 2319-7064 \\ Index Copernicus Value (2013): 6.14 | Impact Factor (2015): 6.391}

Table 5.5 shows the existence or nonexistence of the training programmes in both private and public secondary schools. From the private secondary schools, the total for the very poor and poor categories constituted $6.9 \%$ and good, very good and excellent categories constituted $93.1 \%$. This then implies that the appraisal system is more effective at private secondary schools since training programmes are put in place to correct weaknesses identified on the part of the teachers. From the public secondary schools, the total for the very poor and poor categories constituted $99 \%$ and good, very good and excellent categories constituted $1 \%$. This reflects a very serious situation that needs quick redress if the teaching profession is to restore its glorious status. Failure to have training programmes for teachers in the public secondary schools has resulted in poor pass rate at national level. The past two years have registered pass rates of $19 \%$ and $18 \%$ respectively nationally.

Table 5.5: Availability of training programs by type of school

\begin{tabular}{|c|c|c|c|c|c|c|c|}
\hline \multirow{2}{*}{$\begin{array}{c}\text { Type of } \\
\text { school }\end{array}$} & & \multicolumn{5}{|c|}{ Availability of training programs } & \multirow[b]{2}{*}{ Total } \\
\hline & & Very poor & Poor & Good & Very Good & Excellent & \\
\hline \multirow[t]{3}{*}{ Private } & Count & 1 & 18 & 114 & 138 & 4 & 275 \\
\hline & $\%$ within Type of school & $.4 \%$ & $6.5 \%$ & $41.5 \%$ & $50.2 \%$ & $1.5 \%$ & $100.0 \%$ \\
\hline & $\%$ of Total & $.2 \%$ & $2.7 \%$ & $17.4 \%$ & $21.1 \%$ & $.6 \%$ & $42.0 \%$ \\
\hline \multirow[t]{3}{*}{ Public } & Count & 73 & 303 & 2 & 2 & 0 & 380 \\
\hline & $\%$ within Type of school & $19.2 \%$ & $79.7 \%$ & $.5 \%$ & $.5 \%$ & $.0 \%$ & $100.0 \%$ \\
\hline & $\%$ of Total & $11.1 \%$ & $46.3 \%$ & $.3 \%$ & $.3 \%$ & $.0 \%$ & $58.0 \%$ \\
\hline \multirow[t]{3}{*}{ Total } & Count & 74 & 321 & 116 & 140 & 4 & 655 \\
\hline & $\%$ within Type of school & $11.3 \%$ & $49.0 \%$ & $17.7 \%$ & $21.4 \%$ & $.6 \%$ & $100.0 \%$ \\
\hline & $\%$ of Total & $11.3 \%$ & $49.0 \%$ & $17.7 \%$ & $21.4 \%$ & $.6 \%$ & $100.0 \%$ \\
\hline
\end{tabular}

Table 5.6 shows the evaluation of teachers based on the set standards. From the private secondary schools, the poor category constituted $5.1 \%$ and the good, very good and excellent categories constituted $94.9 \%$. This implies that private secondary schools set standards of achievement upon which teachers are evaluated. Respondents from the private secondary schools interviewed pointed out that those teachers who perform below par face the risk of dismal.
From the public secondary school, the poor category constituted $38 \%$ and the good, very good and excellent categories constituted $62 \%$. Some of the respondents from the public secondary schools were saying that they are still in the field despite being rated poorly. The poor national pass rate that the Zimbabwean education system reports year in, year out is a result of teachers who do not meet the set teaching standards.

Table 5.6: Evaluation focused on standards by type of school

\begin{tabular}{|c|c|c|c|c|c|c|}
\hline & & \multicolumn{4}{|c|}{ Evaluation focused on standards } & \multirow[b]{2}{*}{ Total } \\
\hline & & Poor & Good & Very Good & Excellent & \\
\hline \multirow{6}{*}{$\begin{array}{c}\text { Type of school Private } \\
\text { Public }\end{array}$} & Count & 14 & 89 & 154 & 18 & 275 \\
\hline & $\%$ within Type of school & $5.1 \%$ & \multirow{2}{*}{$\begin{array}{l}32.4 \% \\
13.6 \%\end{array}$} & \multirow{2}{*}{$\begin{array}{l}56.0 \% \\
23.5 \%\end{array}$} & \multirow{2}{*}{$\begin{array}{l}6.5 \% \\
2.7 \%\end{array}$} & $100.0 \%$ \\
\hline & $\%$ of Total & $2.1 \%$ & & & & $42.0 \%$ \\
\hline & Count & 234 & 143 & 3 & 0 & 380 \\
\hline & $\%$ within Type of school & $61.6 \%$ & \multirow{2}{*}{$\begin{array}{l}37.6 \% \\
21.8 \%\end{array}$} & \multirow{2}{*}{$\begin{array}{l}.8 \% \\
.5 \%\end{array}$} & \multirow{2}{*}{$\begin{array}{l}.0 \% \\
.0 \%\end{array}$} & $100.0 \%$ \\
\hline & $\%$ of Total & $35.7 \%$ & & & & $58.0 \%$ \\
\hline \multirow[t]{3}{*}{ Total } & Count & 248 & 232 & 157 & 18 & 655 \\
\hline & $\%$ within Type of school & $37.9 \%$ & \multirow{2}{*}{$\begin{array}{l}35.4 \% \\
35.4 \%\end{array}$} & \multirow{2}{*}{$\begin{array}{l}24.0 \% \\
24.0 \%\end{array}$} & \multirow{2}{*}{$\begin{array}{l}2.7 \% \\
2.7 \%\end{array}$} & $100.0 \%$ \\
\hline & $\%$ of Total & $37.9 \%$ & & & & $100.0 \%$ \\
\hline
\end{tabular}

\section{Suggestions and Recommendations}

In an effective organization, work is planned in advance. This includes setting performance expectations and goals for individuals in order to channel efforts toward achieving organizational objectives. Involving employees in the planning process is essential to their understanding of the goals of the organization, what needs to be done, why it needs to be done, and expectations for accomplishing goals.

Effective and timely feedback during the performance appraisal period addressing employee performance on elements and standards is an essential component of a successful performance appraisal system. Employees need to know in a timely manner how well they are performing. They need to be told what they are doing well and if there are areas needing improvement.
Feedback can come from many different sources: observation by school head and head of department, feedback from colleagues and from students, just to name a few. It will be up to rating officials to determine how best to gather the information, and from which sources, to ensure an effective rating of the employees under their supervision.

\section{Conclusion}

Participants have shown their concerns about lack of communication, less emphasis on performance review meetings and uni-source performance evaluation system. However, private secondary schools have implemented new Performance Appraisal system with more emphasis on training. In public secondary schools, teachers are concerned about their training needs and comprehensive performance evaluation. Current research in this paper, has explored number of operational issues regarding ineffective 
communication between heads and teachers. The study showed that reality was far from the ideal. Heads stressed time pressure. Teachers are less motivated because they are not been encouraged by their heads. Appraisal process is ambiguous because of no clear guidance for conducting it. Teachers and departmental heads use to hesitate performance reviews for avoiding potential conflicts and incompetence of department heads because of no training for this process.

Performance appraisals are important for staff motivation, attitude and behaviour development, communicating organizational aims and fostering positive relationships between management and staff. They provide a formal, recorded, regular review of an individual's performance and a plan for future development. One of the responsibilities of appraisers is to ensure that an organization functions effectively and efficiently. In order to achieve these goals, appraisers must be able to determine and assess performance levels of both an organization and its individual employees (Kurt 2004).

It is extremely important that workers have the proper knowledge, skills and attitudes to perform well in their jobs. Knowledge, skills and attitudes are the internal competencies that workers bring with them to the job or that they must learn through training.

\section{References}

[1] Bartlett S (2000). The development of teacher appraisal: A recent history. British Journal of Educational Studies, 48:24-37.

[2] Bacal, R. (1999) PerformanceManagement, McGrawHill, USA.

[3] Freire, P. (1993). Pedagogy of the oppressed. London: Penguin Books.

[4] Stronge, J.H. (2006) Evaluating Teaching, 2nd. Ed, Corwin Press, California.

[5] Toch, T., and Rothman.R. (2008). "Rush to judgment: Teacher evaluation in public education," Education Sector.

[6] Tziner, A, Murphy, K. and Cleveland, J. N. (2001). Relationships between Attitudes toward Organizations and Performance Appraisal Systems and Rating Behaviour. International Journal of Selection and Assessment, V. 9, No. 3, September 2001.

[7] Tziner, A. and Kopelman, R.E. (2002). Is there a Preferred Performance Rating Format? A Nonpsychometric Perspective. Applied Psychology: An International Review, 51 (3), 479-503

[8] Wanzare Z.O (2002). Rethinking teacher e valuation in the third world. Educational Management and Administration, 30:213-229. 